UDC 613.6.02

DOI: 10.21668/health.risk/2017.3.12.eng

\title{
A PRIORI ASSESSMENT OF OCCUPATIONAL HEALTH RISK FOR VEGETABLES GREENHOUSE WORKERS
}

\author{
A.G. Migacheva ${ }^{1}$, T.A. Novikova ${ }^{1}$, V.F. Spirin ${ }^{1}$, D.M. Shlyapnikov ${ }^{2}$ \\ ${ }^{1}$ Saratov scientific research institute of rural hygiene, 1A Zarechnaya Str., Saratov, 410022, Russian Federation \\ ${ }^{2}$ Federal Service for Surveillance on Consumer Rights Protection and Human Wellbeing, 82 Monastyrskaya Str., \\ Perm, 614045, Russian Federation
}

We performed comprehensive hygienic examination of working conditions in greenhouses at a greenhouse complex in Saratov region. Our research goal was to a priori assess occupational health risk for greenhouse workers on the basis of working conditions classification as per deviations of environment parameters and working process from the existing hygienic standards. We examined microclimate parameters in cold and warm seasons, contamination or working area air with hazardous chemicals and aerosols; we also performed occupational and time studies of work activities when basic working tasks were accomplished during an annual vegetables growing cycle in greenhouses. We detected that greenhouse workers during their working activity were exposed to a set of hazardous factors; the prevailing ones were heating microclimate, occurrence of hazardous chemicals and dust in increased concentrations in working area air, hardness of labor process which involved excessive physical exercise, long-term work in an inconvenient posture, frequent body bendings, and necessity to spend a lot of time standing. Overall hygienic assessment of greenhouse working conditions corresponded to 3 degree category of hazardous conditions (3.3 danger class) allowing for impacts exerted by a set of hazardous working environment factors and working process itself during annual working cycle. Hazardous working conditions caused occupational health risk for greenhouse workers which, in conformity with $R$ 2.21766-03, corresponded to high (intolerable) risk when urgent activities aimed at its reduction were to be accomplished. Our research result prove that it is vital to perform further research on greenhouse workers health as per data on periodical medical examinations, more profound study of morbidity with temporary disablement, and other socially significant health parameters.

Key words: greenhouse workers, working conditions, hazardous production factors, occupational health risk, a priori assessment.

Nowadays new technologies are being implemented in the sphere of greenhouses cultures growing; they involve replacement of soil mixtures with hydroponic substrates (coir fiber, silicate cotton, etc.), automation and mechanization of all technological processes, introduction of fertilizers solution to each plant through a drop watering system. But all these innovations unfortu- nately haven't resulted in elimination of all the working process factors which can be hazardous for greenhouse workers' health. Occupational activities of greenhouse workers still involve functioning under unfavorable microclimate determined by specific technological processes and increased leak resistance of cultivating facilities, contacts with pesticides, agricultural chemicals

(C) Migacheva A.G., Novikova T.A., Spirin V.F., Shlyapnikov D.M., 2017

Anna G. Migacheva - junior researcher of occupational medicine department (e-mail: migachevaag@yandex.ru; tel.: +7(8452) 92-34-94).

Tamara A. Novikova - Candidate of Biological Sciences, Associate Professor, Head of occupational medicine department (e-mail: novikovata-saratov@yandex.ru; tel.: +7(8452)34-71-84).

Vladimir F. Spirin - Doctor of Medical Sciences, Professor, Deputy Director for Research, Development and Innovative Technologies (e-mail: niusgsar@mail.ru; tel.: +7(8452)92-30-48).

Dmitriy M. Shlyapnikov - Candidate of Medical Sciences, Head of Health risks analysis department (email: Shlyapnikov@fcrisk.ru; tel.: +7 (342)238-33-37). 
and products of their destruction, biological protection agents and disinfecting agents, as well as by labor process hardness and intensity $[2,4,7,8,11]$. Our analysis of scientific literature proves that hazardous working conditions exert negative impacts on female greenhouse workers [1,3,5]. Unfavorable working conditions are risk factors causing general and occupational diseases evolvement in greenhouse workers; such diseases may lead to temporary and, in some cases, to persistent lost of working capacities [12,13,14,15].

Given all the above-stated, examination and hygienic assessment of working conditions which exist in the sphere of greenhouse plants cultivating and creation of preventive activities aimed at eliminating occupational diseases risk for greenhouse workers' health can be considered vital.

Our research goal was to perform a priori assessment of occupational risks for vegetables greenhouse workers' health on the basis of working conditions classification as per degree of deviations in working environment parameters and labor process form the existing hygienic standards.

Data and methods. We accomplished our research on one of large greenhouse complexes in Saratov region specializing in year-round growing of tomatoes and cucumbers on hydroponic substrate. We carried out complex hygienic examinations of working conditions which a basic occupational group - vegetable growers - had to work under. We examined microclimate parameters, working area air contamination with hazardous chemicals and sprays; we performed occupational and time studies of working activities when basic working tasks were performed during an annual working cycle; all our examination were performed with the use of conventional techniques applied in occupational hygiene and medicine.

Working factors and labor process factors were hygienically assessed as per deviations in their actual parameters from the existing hygienic standards according to $\mathrm{P}$ 2.2.2006-05 [10]. Occupational risk was assessed in conformity with a technique fixed in P 2.2.1766-03 [9].

All the obtained data were statistically processed with the use of Microsoft Office2007 (MS Excel-07, MS Word-07) software, and Statistica 10.0 software.

Results and discussion. A greenhouse complex which was chose as our research object is a complicated engineering construction equipped with all the necessary tools to grow vegetables in conformity with the adopted technology. Vegetables are grown in blocks of greenhouses with glass covers; greenhouses are combined in 4 blocks, each block containing 4 greenhouses (the overall greenhouses square amounts to 24 hectares, each greenhouse square is equal to 1.5 hectares). The complex also has amenity rooms and auxiliary rooms.

Greenhouses are also equipped with stationary technological systems of water heating, ventilations, cover shading, feeding with carbon dioxide, additional lighting, automated regulating and managing the equipment in order to maintain fixed temperature and humidity regime (air temperature for growing cucumbers is to be $19-28^{\circ} \mathrm{C}$ and air humidity, $70-90 \%$; air temperature for growing tomatoes is to be $18-26^{\circ} \mathrm{C}$, and air humidity $60-70 \%$ ).

Lighting in the greenhouses is natural due to glass covers; there is also additional lighting (luminous lamps). Ventilation is also natural (fanlights). Water supply and sewerage are centralized. Water taken from this centralized water supply system is also used for drinking. Heating comes from the 
own boilers which function due to natural gas. Technological processes related to watering and fertilizers introduction, as well as transportation and cargo handling are performed by machines.

Certain stages in the process of vegetables growing in greenhouses require application of agricultural chemicals serving as root-feeding and top-feeding. Topfeeding is a basic way to provide plants with microelements; it is usually done through spraying plants with agricultural chemicals solutions. Root-feeding is done via introducing fertilizers solutions to each plant through a drop watering system. ready solutions are directly fed in these drop watering systems. Vegetable growers don't have any direct contacts with agricultural chemicals. Air feeding of plants is done with carbon dioxide during the whole vegetation period from 7 a.m. to 19 a.m.; preset concentrations are maintained by an automatic regulation system.

To fight plant pests and diseases, pesticides (insecticides and fungicides) are widely used at the complex. Treatment with pesticides is usually performed in the evening by a specialized group of workers who are responsible for plants protection; after it greenhouses usually remain closed for a long period, from 12 to 24 hours. But sometimes vegetable growers enter greenhouses on the next day in the morning thus violating the rules on safety working procedures after chemical treatment with pesticides; it proves that they are exposed to effects exerted by pesticides residues. The examined complex usually applies the 3th generation pesticides which are mostly represented by synthetic pyrethroids and hormonal preparations. Their basic peculiarities are abilities providing faster selfdestruction in the environment. Such biological agents as antibiotics, vitamins, and snouted mites which eliminate plant pests, are also used in the complex activities.

Agricultural technology at the examined complex consists of a number of successive stages which differ in their duration and which are characterized with a complicated structure involving a lot of operations and high labor input required for production processes. These are the main stages which vegetable growers have to perform during their annual working cycle: sowing seeds and taking care of seedlings; seedlings planting; plants formation; harvesting and taking care of plants; plants mass disposal; greenhouses cleaning and disinfecting; getting greenhouses ready for the next working cycle; various maintenance and repair works (painting of equipment, mounts tightening, support columns adjustment, etc.).

Such works as seedlings growing, plants formation, harvesting, and taking care of plants, are the longest stages in the working cycle. During them a specific, artificially created temperature and humidity regime is supported in the greenhouses; this regime involves relatively constant increased air temperature and humidity levels. Works related to plant mass disposal and greenhouses disinfection took place twice a year and lasted from 5-10days up to 1 month a year; they were usually performed with all the doors remaining open and all the climatic systems being switched off.

Our research revealed that unfavorable microclimate was the basic peculiarity of vegetable growers' working conditions at all the production cycle stages (Table 1). Thus, during a warm period (when outdoors temperature was $+20-24^{\circ} \mathrm{C}$ ) indoors air temperature exceeded permissible levels. It was the highest (by $4-8^{\circ} \mathrm{C}$ than the permissible one) during such works as taking care of plants and harvesting. Envi- 
ronmental heat load index (EHL-index) which reflected combined effects exerted by air temperature, its motion speed, and its humidity, on a human heat exchange with the environment, exceeded permissible values by $2,3^{\circ} \mathrm{C}-3,0^{\circ} \mathrm{C}$ during this period.

When the same operations were performed during a cold time of a the year, air temperature was on average $7,8^{\circ} \mathrm{C}$ higher than the permissible one, and the EHLindex was $2,1^{\circ} \mathrm{C}$ higher. Relative air humidity exceeded its permissible levels by $2-5 \%$ practically during all the production cycle stages. Air mobility in the greenhouses was limited and didn't exceed 0.1 $\mathrm{m} / \mathrm{sec}$ while its permissible values vary from 0.2 to $0.5 \mathrm{~m} / \mathrm{sec}$.

Therefore, vegetable growers were exposed to heating microclimate during the whole production cycle in the greenhouses. Hygienic assessment of working conditions as per microclimate parameters corresponded to 3.1 hazard category during seedlings growing and planting, and during plants formation; it corresponded to 3.3 hazard category during taking care of plants, harvesting, and plants mass disposal.

Heating microclimate (increased air temperature, high humidity, and limited air mobility) during a working shift together with intensive physical activity exerted negative impacts on heating state of female workers. When we performed an integral assessment of heating microclimate in conformity with the Methodical Guidelines 4.3.2755-10 [6], we revealed that risk of females' bodies overheating ranged from moderate to very high during a warm period of the year, and heat accumulation in the body ranged from 2.66 to $4.56 \mathrm{~kJ} / \mathrm{kg}$. Risk of overheating ranged from weak to moderate during a cold period of the year.

Air environment in the greenhouses was contaminated with hazardous chemicals at all the production cycle stages. Working area air was constantly contaminated with carbon dioxide which was fed to plants during the periods of plants formation and harvesting. Carbon dioxide concentrations didn't exceed MPC 650 ppm). However, carbon dioxide is known to exert negative influence on human

Table 1

Hygienic assessment of microclimate parameters during various works performed by greenhouse vegetable growers

\begin{tabular}{|c|c|c|c|c|c|c|c|c|c|c|c|c|c|c|c|c|c|c|c|}
\hline \multirow{3}{*}{$\begin{array}{l}\text { Works } \\
\text { (number of } \\
\text { research) }\end{array}$} & \multirow{3}{*}{ 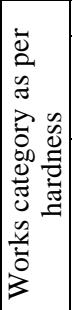 } & \multicolumn{8}{|c|}{ Warm period } & \multirow{3}{*}{ 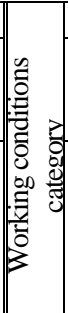 } & \multicolumn{8}{|c|}{ Cold period } & \multirow{3}{*}{ 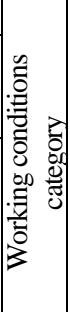 } \\
\hline & & \multicolumn{2}{|c|}{$\begin{array}{c}\text { Air } \\
\text { temperature, } \\
{ }^{\circ} \mathrm{C} \\
\end{array}$} & \multicolumn{2}{|c|}{$\begin{array}{c}\text { EHL-index, } \\
{ }^{\circ} \mathrm{C}\end{array}$} & \multicolumn{2}{|c|}{$\begin{array}{l}\text { Relative air } \\
\text { humidity, \% }\end{array}$} & \multicolumn{2}{|c|}{$\begin{array}{l}\text { Air speed, } \\
\mathrm{m} / \mathrm{sec}\end{array}$} & & \multicolumn{2}{|c|}{$\begin{array}{c}\text { Air } \\
\text { temperature, } \\
{ }^{\circ} \mathrm{C}\end{array}$} & \multicolumn{2}{|c|}{$\begin{array}{c}\text { EHL-index, } \\
{ }^{\circ} \mathrm{C}\end{array}$} & \multicolumn{2}{|c|}{$\begin{array}{l}\text { Relative air } \\
\text { humidity, \% }\end{array}$} & \multicolumn{2}{|c|}{$\begin{array}{l}\text { Air speed, } \\
\mathrm{m} / \mathrm{sec}\end{array}$} & \\
\hline & & 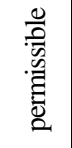 & 䒱 & 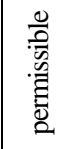 & 㐨 & $\begin{array}{l}\frac{0}{2} \\
\frac{0}{0} \\
\frac{0}{0} \\
\varrho\end{array}$ & 胥 & 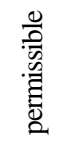 & 卺 & & $\begin{array}{l}\frac{0}{0} \\
\frac{\pi}{2} \\
. \frac{0}{E} \\
\frac{0}{0} \\
\varrho\end{array}$ & 胥 & $\begin{array}{l}\frac{0}{0} \\
\frac{0}{0} \\
\frac{0}{E} \\
\frac{0}{2}\end{array}$ & 胥 & 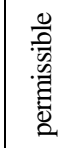 & 胥 & 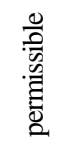 & 楚 & \\
\hline $\begin{array}{l}\text { Growing and planting } \\
\text { seedlings }(n=136)\end{array}$ & III & $\begin{array}{c}15,0- \\
26,0 \\
\end{array}$ & $\begin{array}{c}25,7 \pm \\
1,5\end{array}$ & $\begin{array}{l}18,0- \\
21,8\end{array}$ & $\begin{array}{c}22,8 \pm \\
1,2\end{array}$ & $15-75$ & $66 \pm 4$ & $\begin{array}{c}0,3- \\
0,5 \\
\end{array}$ & \begin{tabular}{|c|}
$0,43 \pm$ \\
0,24 \\
\end{tabular} & 3.1 & $\begin{array}{c}17,0- \\
23,0 \\
\end{array}$ & $\begin{array}{c}27,6 \pm \\
0,4\end{array}$ & $\begin{array}{r}20,5- \\
25,1 \\
\end{array}$ & $\begin{array}{c}25,5 \pm \\
0,2\end{array}$ & -75 & $66 \pm 4$ & $\begin{array}{c}0,1- \\
0,3 \\
\end{array}$ & $\begin{array}{c}0,17 \pm \\
0,24\end{array}$ & 3.1 \\
\hline $\begin{array}{l}\text { Plants formation } \\
(\mathrm{n}=136)\end{array}$ & IIa & $\begin{array}{c}18,0- \\
27,0 \\
\end{array}$ & $\begin{array}{c}28,1 \pm \\
1,0\end{array}$ & $\begin{array}{c}20,5- \\
25,1\end{array}$ & $\begin{array}{c}25,2 \pm \\
1,4\end{array}$ & $15-75$ & $66 \pm 4$ & $\begin{array}{c}0,2- \\
0,4 \\
\end{array}$ & \begin{tabular}{c||}
$0,2 \pm$ \\
0,1 \\
\end{tabular} & 3.1 & \begin{tabular}{|c|}
$17,0-$ \\
23,0 \\
\end{tabular} & $\begin{array}{c}22,8 \pm \\
0,4\end{array}$ & $\begin{array}{l}20,5- \\
25,1 \\
\end{array}$ & - & $15-75$ & $66 \pm 2$ & $\begin{array}{c}0,1- \\
0,3 \\
\end{array}$ & $\begin{array}{c}0,15 \pm \\
0,04\end{array}$ & 2 \\
\hline $\begin{array}{l}\text { Harvesting } \\
(\mathrm{n}=320)\end{array}$ & III & $\begin{array}{c}15,0- \\
26,0 \\
\end{array}$ & $\begin{array}{c}29,4 \pm \\
3,5 \\
\end{array}$ & $\begin{array}{l}18,0- \\
21,8 \\
\end{array}$ & $\begin{array}{c}26,3 \pm \\
3,4 \\
\end{array}$ & $15-75$ & $\begin{array}{c}71 \pm \\
10 \\
\end{array}$ & $\begin{array}{c}0,3- \\
0,5 \\
\end{array}$ & $\begin{array}{c}0,17 \pm \\
0,14 \\
\end{array}$ & 3.3 & \begin{tabular}{|c|}
$13,0-$ \\
21,0 \\
\end{tabular} & $\begin{array}{c}25,7 \pm \\
0,6\end{array}$ & \begin{tabular}{|l}
$18,0-$ \\
21,8 \\
\end{tabular} & $\begin{array}{c}22,4 \pm \\
0,7 \\
\end{array}$ & $15-75$ & $77 \pm 6$ & $\begin{array}{c}0,2- \\
0,4 \\
\end{array}$ & \begin{tabular}{|c|}
$0,13 \pm$ \\
0,04
\end{tabular} & 3.1 \\
\hline $\begin{array}{l}\text { Taking care of plants } \\
(\mathrm{n}=292)\end{array}$ & $\mathrm{Ilb}$ & $\begin{array}{c}16,0- \\
27,0 \\
\end{array}$ & $\begin{array}{c}30,4 \pm \\
3,6 \\
\end{array}$ & $\begin{array}{l}19,5- \\
23,9 \\
\end{array}$ & $\begin{array}{c}27,3 \pm \\
3,2 \\
\end{array}$ & $15-75$ & $\begin{array}{c}71 \pm \\
12 \\
\end{array}$ & $\begin{array}{c}0,2- \\
0,5 \\
\end{array}$ & \begin{tabular}{|c|}
$0,15 \pm$ \\
0,06
\end{tabular} & 3.3 & $\begin{array}{c}15,0- \\
22,0 \\
\end{array}$ & $\begin{array}{c}26,0 \pm \\
0,6\end{array}$ & $\begin{array}{l}19,5- \\
23,9 \\
\end{array}$ & $\begin{array}{c}22,6 \pm \\
0,2\end{array}$ & $15-75$ & $74 \pm 7$ & $\begin{array}{c}0,2- \\
0,4 \\
\end{array}$ & $\begin{array}{c}0,12 \pm \\
0,03 \\
\end{array}$ & 3.1 \\
\hline $\begin{array}{l}\text { Plants mass disposal } \\
(\mathrm{n}=165)\end{array}$ & $\mathrm{Ilb}$ & $\begin{array}{c}16,0- \\
27,0 \\
\end{array}$ & $\begin{array}{c}33,6 \pm \\
0,9\end{array}$ & $\begin{array}{l}19,5- \\
23,9 \\
\end{array}$ & $\begin{array}{c}29,0 \pm \\
1,2\end{array}$ & $15-75$ & $\begin{array}{c}54 \pm \\
11 \\
\end{array}$ & $\begin{array}{c}0,2- \\
0,5 \\
\end{array}$ & $\begin{array}{c}0,3 \pm \\
0,09 \\
\end{array}$ & 3.3 & \begin{tabular}{|l|}
$15,0-$ \\
22,0
\end{tabular} & $\begin{array}{c}17,2 \pm \\
2,7 \\
\end{array}$ & $\begin{array}{l}19,5- \\
23,9 \\
\end{array}$ & - & $15-75$ & \begin{tabular}{|c|}
$70 \pm$ \\
10 \\
\end{tabular} & $\begin{array}{c}0,2- \\
0,4 \\
\end{array}$ & \begin{tabular}{|c|}
$0,16 \pm$ \\
0,04
\end{tabular} & 2 \\
\hline
\end{tabular}


health under regular and long-term exposure to it.

Greenhouses plants were treated with pesticides during the stage of taking care of plants; the task was performed in the evening by a special group of experts on plants protection. But terms of safe entrance to the greenhouses after such treatment were often violated at the complex, and vegetable growers were exposed to pesticides in concentrations which were 1.1-2 times higher than MPC during the whole year (3.1 hazard category).

When workers performed tasks related to plants mass cutting and getting plants residues ready for disposal, we detected formaldehyde in concentrations 1.4 times higher than MPC and phytogenic dust in concentrations 1.17 times higher than MPC in working area air. Working conditions were assigned into 3.1 hazard category as per working area air contamination with dust and hazardous substances.

Basic working tasks in the process of performing all the technological operations were handled manually and involved substantial physical dynamic loads on arms, body, and legs muscles, as well as static loads appearing when cargoes weighing 10 and more $\mathrm{kg}$ were lifted and moved and when a body was frequently bent over by more than 30 degrees. Vegetable growers had to work in a standing position during $85-90 \%$ of a working shift performing all types of working tasks and they had to constantly move around an area they were responsible for. Labor process hardness for vegetable growers corresponded to 3.2 and 3.3 hazard category when they performed working tasks at all the production cycle stages (Table 2).

Overall assessment of working conditions which greenhouse vegetable growers had to work under allowing for influence exerted by a set of hazardous working environment factors corresponded to 3.2 and 3.3 hazard category when various working tasks were performed by them during all the production cycle stages (Table 3 ).

Table 2

Assessment of labor process hardness for greenhouses vegetable growers during basic working tasks performance

\begin{tabular}{|c|c|c|c|c|c|c|c|}
\hline \multirow{3}{*}{$\begin{array}{l}\text { Working } \\
\text { tasks }\end{array}$} & \multicolumn{6}{|c|}{ Labor process hardness parameters } & \multirow{3}{*}{$\begin{array}{c}\text { Overall } \\
\text { labor } \\
\text { hardness } \\
\text { assessment }\end{array}$} \\
\hline & \multirow[b]{2}{*}{$\begin{array}{c}\text { Physical } \\
\text { dynamic load } \\
(\mathrm{kg} \bullet \mathrm{m})\end{array}$} & \multirow[b]{2}{*}{$\begin{array}{c}\text { Static } \\
\text { load } \\
(\mathrm{kg} \bullet \mathrm{sec})\end{array}$} & \multirow{2}{*}{$\begin{array}{l}\text { Weight of a } \\
\text { cargo being } \\
\text { lifted and } \\
\text { moved }(\mathrm{kg})\end{array}$} & \multicolumn{2}{|c|}{ Working posture } & \multirow{2}{*}{$\begin{array}{c}\text { Body } \\
\text { bendings, } \\
\text { times per } \\
\text { shift }\end{array}$} & \\
\hline & & & & $\begin{array}{c}\text { standing, } \\
\% \text { of a } \\
\text { shift }\end{array}$ & \begin{tabular}{|c|} 
Posture character- \\
istics, $(\%$ of a \\
shift $)$
\end{tabular} & & \\
\hline \multirow{2}{*}{\begin{tabular}{|l|} 
Seedlings \\
growing and \\
planting \\
\end{tabular}} & \multirow[t]{2}{*}{$\begin{array}{c}6840, \\
2 \text { category }\end{array}$} & \multirow{2}{*}{\begin{tabular}{|c|}
$\begin{array}{c}97172, \\
3.1 \text { cate- } \\
\text { gory }\end{array}$ \\
\end{tabular}} & \multirow[t]{2}{*}{$\begin{array}{c}9, \\
3.1 \text { category }\end{array}$} & 92 & $\begin{array}{c}53 \% \text { inconvenient } \\
10 \% \text { forced }\end{array}$ & \multirow{2}{*}{$\begin{array}{c}582, \\
3.2 \text { category }\end{array}$} & \multirow{2}{*}{$\begin{array}{c}3.3 \text { catego- } \\
\text { ry }\end{array}$} \\
\hline & & & & & 2 category & & \\
\hline \multirow{2}{*}{$\begin{array}{l}\text { Plants for- } \\
\text { mation }\end{array}$} & \multirow{2}{*}{$\begin{array}{c}1500 \\
2 \text { category }\end{array}$} & \multirow{2}{*}{$\begin{array}{c}25467, \\
2 \text { catego- } \\
\text { ry }\end{array}$} & \multirow{2}{*}{$\begin{array}{c}3, \\
2 \text { category }\end{array}$} & 75 & $30 \%$ inconvenient & \multirow{2}{*}{$\begin{array}{c}210 \\
3.1 \text { category }\end{array}$} & \multirow{2}{*}{$\begin{array}{c}3.2 \text { catego- } \\
\text { ry }\end{array}$} \\
\hline & & & & \multicolumn{2}{|c|}{3.1 category } & & \\
\hline \multirow[t]{2}{*}{$\begin{array}{l}\text { Harvesting } \\
\text { and taking } \\
\text { care of plants }\end{array}$} & \multirow[t]{2}{*}{$\begin{array}{c}4560 \\
2 \text { category }\end{array}$} & \multirow[t]{2}{*}{$\begin{array}{c}39125, \\
2 \text { catego- } \\
\text { ry }\end{array}$} & \multirow[t]{2}{*}{$\begin{array}{c}10, \\
3.1 \text { category }\end{array}$} & 93 & $\begin{array}{c}63 \% \\
\text { inconvenient, } \\
15 \% \text { forced } \\
\end{array}$ & \multirow[t]{2}{*}{$\begin{array}{c}297, \\
3.1 \text { category }\end{array}$} & \multirow[t]{2}{*}{$\begin{array}{c}3.2 \text { catego- } \\
\text { ry }\end{array}$} \\
\hline & & & & \multicolumn{2}{|c|}{3.2 category } & & \\
\hline \multirow[t]{2}{*}{$\begin{array}{l}\text { Plants mass } \\
\text { disposal }\end{array}$} & \multirow[t]{2}{*}{$\begin{array}{c}26560 \\
2 \text { category }\end{array}$} & \multirow[t]{2}{*}{$\begin{array}{c}41180, \\
2 \text { catego- } \\
\text { ry }\end{array}$} & \multirow[t]{2}{*}{$\begin{array}{c}7, \\
2 \text { category }\end{array}$} & 90 & $\begin{array}{c}30 \% \\
\text { inconvenient, } \\
10 \% \text { forced }\end{array}$ & \multirow[t]{2}{*}{$\left|\begin{array}{c}220 \\
3.1 \text { category }\end{array}\right|$} & \multirow[t]{2}{*}{$\begin{array}{c}3.2 \text { catego- } \\
\text { ry }\end{array}$} \\
\hline & & & & & ate & & \\
\hline
\end{tabular}


Table 3

Hygienic assessment of vegetable growers' working conditions when they performed basic working tasks

\begin{tabular}{|l|c|c|c|c|c|}
\hline \multirow{2}{*}{ Working tasks } & \multicolumn{3}{|c|}{ Working environment factors } & \multirow{2}{*}{$\begin{array}{c}\text { Overall working } \\
\text { conditions assess- } \\
\text { ment as per P } \\
2.2 .2006-05\end{array}$} \\
\cline { 2 - 5 } & Chemical & Microclimate & $\begin{array}{c}\text { Fibrogenic } \\
\text { aerosols } \\
\text { phytogenic } \\
\text { dust) }\end{array}$ & Labor hardness & \\
\hline $\begin{array}{l}\text { Seedlings growing and } \\
\text { planting }\end{array}$ & 2 & 3.1 & - & 3.3 & 3.3 \\
\hline Plants formation & 2 & 3.1 & - & 3.2 & 3.2 \\
\hline $\begin{array}{l}\text { Harvesting and taking } \\
\text { care of plants }\end{array}$ & 3.2 & 3.3 & 2 & 3.2 & 3.3 \\
\hline Plants mass disposal & 3.1 & 3.3 & 3.1 & 3.2 & 3.3 \\
\hline
\end{tabular}

Table 4

Parameters and criteria of vegetable growers' occupational risk assessment when they performed basic working tasks

\begin{tabular}{|l|c|c|c|}
\hline \multirow{2}{*}{ Working tasks } & \multicolumn{3}{|c|}{ A priori risk parameters (as per P 2.2.1766-03) } \\
\cline { 2 - 4 } & $\begin{array}{c}\text { Working conditions } \\
\text { category } \\
\text { (as per P 2.2.2006-05) }\end{array}$ & Occupational risk category & $\begin{array}{c}\text { Urgency of activities aimed at } \\
\text { risk lowering }\end{array}$ \\
\hline $\begin{array}{l}\text { Seedlings growing and } \\
\text { planting }\end{array}$ & 3.3 & High (intolerable) & Urgent activities are required \\
\hline Plants formation & 3.2 & Average (significant) & $\begin{array}{c}\text { Actions are to be taken in due } \\
\text { time }\end{array}$ \\
\hline $\begin{array}{l}\text { Harvesting and taking } \\
\text { care of plants }\end{array}$ & 3.3 & High (intolerable) & Urgent activities are required \\
\hline Plants mass disposal & 3.3 & High (intolerable) & Urgent activities are required \\
\hline
\end{tabular}

A priori assessment of occupational risk which was performed in accordance with the techniques stated in the Guide $\mathrm{P}$ 2.2.1766-03, allowed us to reveal that risk for vegetable growers' health varied from insignificant (moderate) to very high (intolerable) during the whole annual production cycle depending on working tasks performed by them (Table 4).

Therefore, in spite of new technologies implementation, greenhouse vegetable growers are exposed to impacts exerted by a set of hazardous factors during their working activities; these factors include heating microclimate, working are air contamination with hazardous chemicals, and labor process hardness.

\section{Conclusions.}

1. Integral assessment of working conditions which greenhouse vegetable growers had to work under was performed in conformity with the Guide P 2.2.2.2006-05 as per aggregation of all the working environment factors exerting their influence on workers' health during the whole production cycle. the assessment revealed that working conditions belonged to 3.3 hazard category.

2. We detected "high intolerable" occupational risk for vegetable growers' health and it proves that further research on health of workers from this occupational group is required. This research can be based on data obtained during periodical 
medical check-ups, more profound exami- rary disability, and other socially signifination of their morbidity causing tempo- cant health parameters.

\section{References}

1. Klepikov O.V., Mamchik N.P., Gabbasova N.V., Kalashnikov Yu.S. Vliyanie uslovii truda na sostoyanie zdorov'ya rabochikh $\mathrm{v}$ teplichnom proizvodstve [Influence of work conditions on health state of workers engaged into hothouse production]. Meditsina truda i promyshlennaya ekologiya, 2016, no.7, pp. 21-25 (in Russian).

2. Mamchik N.P., Borisova L.S., Kameneva O.V. Gigienicheskie aspekty formirovaniya zabolevaemosti rabotnikov teplichnykh khozyaistv [Hygiene-related diseases of greenhouse workers]. Nauchno-meditsinskii vestnik Tsentral'nogo Chernozem'ya, 2014, no. 58, pp. 3-9 (in Russian).

3. Migacheva A.G. Sostoyanie uslovii truda i ikh vliyanie na zdorov'e ovoshchevodov zashchishchennogo grunta [The state of labor conditions and their impact on health of vegetable-growing workers of secure soil]. Zdravookhranenie Rossiiskoi Federatsii, 2013, no. 6, pp. 47-48 (in Russian).

4. Migacheva A.G., Spirin V.F. Otsenka professional'nogo riska zdorov'yu ovoshchevodov zashchishchennogo grunta po gigienicheskim i mediko-biologicheskim pokazatelyam [Assessment of occupational health risk greenhouse workers on the hygienic and medical and biological indicators]. Zdorov'e naseleniya i sreda obitaniya, 2016, no. 9, pp. 28-32 (in Russian).

5. Moiseeva I.V., Borisova L.S., Yatsyna D.S. Rol' proizvodstvennykh faktorov v formirovanii sostoyaniya zdorov'ya u rabotnikov teplichnogo khozyaistva [Contribution made by production factors into greenhouse workers' health state]. Gigiena, toksikologiya, profpatologiya: traditsii i sovremennost': Materialy Vserossiiskoi nauchno-prakticheskoi konferentsii s mezhdunarodnym uchastiem [Hygiene, toxicology, and occupational pathology: traditions and today situation: Materials of Russian theoretical and practical conference with international participation]. In: A.Yu. Popova, V.N. Rakitskii, eds. Moscow, 2016, pp. 514-517 (in Russian).

6. MUK 4.3.2755-10. Integral'naya otsenka nagrevayushchego mikroklimata: Metodicheskie ukazaniya [MG 4.3.2755-10. Integral assessment of heating microclimate: Methodical guidelines]. Moscow, Federal'nyitsentrgigienyiepidemiologii, Publ. Available at: http://docs.cntd.ru/document/1200087779 (22.05.2017) (in Russian).

7. Novikova T.A., Spirin V.F., Mikhailova N.A. [et al.]. Professional'nyi risk dlya zdorov'ya rabotnikov sel'skogo khozyaistva, gigienicheskie aspekty ego otsenki i upravleniya (obzor literatury) [Occupational hazard of agricultural workers health, hygienic aspects of its appraisal and management. (A survey of literature)]. Meditsina truda i promyshlennaya ekologiya, 2012, no. 5, pp. 22-28 (in Russian).

8. Popova A.Yu. Problemy i tendentsii professional'noi zabolevaemosti rabotnikov sel'skogo khozyaistva Rossiiskoi Federatsii [Issues and trends in occupational morbidity of agricultural workers of the Russian Federation]. Zdorov'e naseleniya i sreda obitaniya, 2016, no. 9, pp. 4-9. (in Russian).

9. R 2.2.1766-03. Rukovodstvo po otsenke professional'nogo riska dlya zdorov'ya rabotnikov. Organizatsionno-metodicheskie osnovy, printsipy i kriterii otsenki: rukovodstvo [Guidelines on occupational health risk assessment. Organizational and methodical grounds, principles, and assessment criteria: guidelines]. Moscow, Federal'nyi tsentr gossanepidnadzora Minzdrava Rossii, Publ., 2004, 24 p. (in Russian). 
10. R 2.2.2006-05. Gigiena truda. Rukovodstvo po gigienicheskoi otsenke faktorov rabochei sredy i trudovogo protsessa. Kriterii i klassifikatsiya uslovii truda: rukovodstvo [Labor hygiene. Guide on hygienic assessment of working environment factors and working processes factors. Working conditions criteria and classification: guidelines]. Availableat: http://docs.cntd.ru/document/1200040973 (14.02.2017) (inRussian).

11. Ryzhkova N.S., Smirnov G.N., Shirokov Yu.A. Problemy uluchsheniya uslovii truda rabotnikov zashchishchennogo grunta [Issues of working conditions improvement for greenhouse workers]. Sovremennye tendentsii razvitiya nauki i tekhnologii, 2017, no. 2-3, pp. 91-94 (in Russian).

12. Wohlfahrt-Veje C., Andersen H.R., Schmidt I.M., Aksglaede L., Sørensen K., Juul A., Jensen T.K., Grandjean P., Skakkebaek N.E., Main K.M. Early breast development in girls after prenatal exposure to non-persistent pesticides. Int. J. Androl., 2012, vol. 35, no. 3, pp. 273-82.

13. Hansen V.M., Meyling N.V., Jørgen Eilenberg A.W., Madsen A.M. Factors Affecting Vegetable Growers' Exposure to Fungal Bioaerosols and Airborne Dust. Ann. Occup. Hyg., 2012, vol. 56, no. 2, pp. 170-181.

14. Barrero L.H., Pulido J.A., Berrio S., Monroy M., Quintana L.A., Ceballos C., HoehneHueckstaedt U., Ellegast R. Physical workloads of the upper-extremity among workers of the Colombian flower industry. American Journal of Industrial Medicine, 2012, vol. 55, no. 10, pp. 926-939.

15. Liu S., Li L.Y., Li Z.H., Wen D.L., Wang X.G. Risk factors on chronic obstructive pulmonary disease among greenhouse workers in Liaoning province. Zhonghua Liu Xing Bing Xue Za Zhi, 2012, vol. 33, no.3, pp. 280-285.

Migacheva A.G., Novikova T.A., Spirin V.F., Shlyapnikov D.M. A priori assessment of occupational health risk for vegetables greenhouse workers. Health Risk Analysis, 2017, no. 3, pp. 101-108. DOI: 10.21668/health.risk/2017.3.12.eng

Received: 19.07.2017

Accepted: 19.09.2017

Published: 30.09.2017 